\title{
Impact of crop residue management on crop production and soil chemistry after seven years of crop rotation in temperate climate, loamy soils
}

\author{
Marie-Pierre Hiel Corresp., ${ }^{1}$, Sophie Barbieux ${ }^{1}$, Jérôme Pierreux ${ }^{2}$, Claire Olivier ${ }^{3}$, Guillaume Lobet ${ }^{4,5}$,

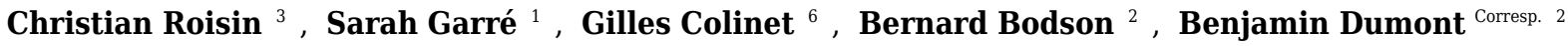 \\ ${ }^{1}$ TERRA Research \& Teaching Center - AgriculturelsLife, Gembloux Agro-Bio Tech, Université de Liège, Liège, Belgium \\ 2 AGROBIOCHEM, Gembloux Agro-Bio Tech, Université de Liège, Liège, Belgium \\ 3 Unit Soil Fertility and Water Protection, Dpt Agriculture and Natural Environment, Walloon Agricultural Research Center, Gembloux, Belgium \\ 4 Earth and Life Institute, Université catholique de Louvain, Louvain-la-Neuve, Belgium \\ 5 Agrosphere, IBG3, Forschungszentrum Juelich, Juelich, Germany \\ 6 BIOSE, Gembloux Agro-Bio Tech, Université de Liège, Liège, Belgium \\ Corresponding Authors: Marie-Pierre Hiel, Benjamin Dumont \\ Email address: mariepierrehiel@gmail.com, benjamin.dumont@ulg.ac.be
}

Society is increasingly demanding a more sustainable management of agro-ecosystems in a context of climate change and an ever growing global population. The fate of crop residues is one of the important management aspects under debate, since it represents an unneglectable quantity of organic matter which can be kept in or removed from the agro-ecosystem. The topic of residue management is not new, but the need for global conclusion on the impact of crop residue management on the agro-ecosystem linked to local pedo-climatic conditions has become apparent with an increasing amount of studies showing a diversity of conclusions. This study specifically focusses on temperate climate and loamy soil using a 7-year data set.

Between 2008 and 2016, we compared four contrasting residue management strategies differing in the amount of crop residues returned to the soil (incorporation vs. exportation of residues) and in the type of tillage (reduced tillage (10 cm depth) vs. conventional tillage (ploughing at $25 \mathrm{~cm}$ depth)) in a field experiment. We assessed the impact of the crop residue management on crop production (three crops winter wheat, faba bean and maize - cultivated over six cropping seasons), soil organic carbon content, nitrate $\left(\mathrm{NO}_{3}{ }^{-}\right)$, phosphorus $(\mathrm{P})$ and potassium $(\mathrm{K})$ soil content and uptake by the crops.

The main differences came primarily from the tillage practice and less from the restitution or removal of residues. All years and crops combined, conventional tillage resulted in a yield advantage of $3.4 \%$ as compared to reduced tillage, which can be partly explained by a lower germination rate observed under reduced tillage, especially during drier years. On average, only small differences were observed for total organic carbon (TOC) content of the soil, but reduced tillage resulted in a very clear stratification of TOC and also of $\mathrm{P}$ and $\mathrm{K}$ content as compared to conventional tillage. We observed no effect of residue management on the $\mathrm{NO}_{3}{ }^{-}$content, since the effect of fertilization dominated the effect of residue management. To confirm the results and enhance early tendencies, we believe that the experiment should be followed up in the future to observe whether more consistent changes in the whole agroecosystem functioning are present on the long term when managing residues with contrasted strategies. 
1 Impact of crop residue management on crop production and soil

2 chemistry after seven years of crop rotation in temperate climate, loamy

3 soils.

4

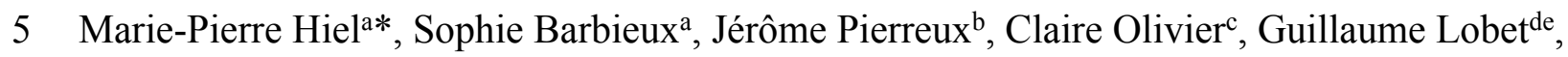

6 Christian Roisin ${ }^{\mathrm{c}}$, Sarah Garréa , Gilles Colinet ${ }^{\mathrm{f}}$, Bernard Bodson ${ }^{\mathrm{b}}$, Benjamin Dumont ${ }^{\mathrm{b}}$.

(a) TERRA Research \& Teaching Center - AgricultureIsLife, Gembloux Agro-Bio Tech, University of Liège, Gembloux, Belgium.

(b) AGROBIOCHEM, Gembloux Agro-Bio Tech, University of Liège, Gembloux, Belgium.

(c) Unit Soil Fertility and Water Protection, Dpt Agriculture and Natural Environment, Walloon Agricultural Research Center, Gembloux, Belgium.

(d) Agrosphere, IBG3, Forschungszentrum Jülich, Jülich, Germany.

(e) Earth and Life Institute, Université catholique de Louvain, Louvain-la-Neuve, Belgium.

(f) BIOSE, Gembloux Agro-Bio Tech, University of Liège, Gembloux, Belgium.

16 Corresponding author:

17 Benjamin Dumont

18 Email address: Benjamin.dumont@uliege.be 


\section{Abstract}

20 Society is increasingly demanding a more sustainable management of agro-ecosystems in a

21 context of climate change and an ever growing global population. The fate of crop residues is

22 one of the important management aspects under debate, since it represents an unneglectable

23 quantity of organic matter which can be kept in or removed from the agro-ecosystem. The topic

24 of residue management is not new, but the need for global conclusion on the impact of crop

25 residue management on the agro-ecosystem linked to local pedo-climatic conditions has become

26 apparent with an increasing amount of studies showing a diversity of conclusions. This study

27 specifically focusses on temperate climate and loamy soil using a 7-year data set.

28 Between 2008 and 2016, we compared four contrasting residue management strategies differing

29 in the amount of crop residues returned to the soil (incorporation vs. exportation of residues) and

30 in the type of tillage (reduced tillage $(10 \mathrm{~cm}$ depth) vs. conventional tillage (ploughing at $25 \mathrm{~cm}$

31 depth)) in a field experiment. We assessed the impact of the crop residue management on crop

32 production (three crops - winter wheat, faba bean and maize - cultivated over six cropping

33 seasons), soil organic carbon content, nitrate $\left(\mathrm{NO}_{3}^{-}\right)$, phosphorus $(\mathrm{P})$ and potassium $(\mathrm{K})$ soil

34 content and uptake by the crops.

35 The main differences came primarily from the tillage practice and less from the restitution or

36 removal of residues. All years and crops combined, conventional tillage resulted in a yield

37 advantage of $3.4 \%$ as compared to reduced tillage, which can be partly explained by a lower

38 germination rate observed under reduced tillage, especially during drier years. On average, only

39 small differences were observed for total organic carbon (TOC) content of the soil, but reduced

40 tillage resulted in a very clear stratification of TOC and also of $\mathrm{P}$ and $\mathrm{K}$ content as compared to

41 conventional tillage. We observed no effect of residue management on the $\mathrm{NO}_{3}{ }^{-}$content, since 
42 the effect of fertilization dominated the effect of residue management. To confirm the results and

43 enhance early tendencies, we believe that the experiment should be followed up in the future to

44 observe whether more consistent changes in the whole agro-ecosystem functioning are present

45 on the long term when managing residues with contrasted strategies.

\section{1. Introduction}

47 Once a crop is harvested, farmers have to decide what to do with the remaining crop residue (the

48 above ground biomass that is cut but not harvested). Residues can be either exported and

49 valorised as co-products (e.g. animal fodder, biogas production), or restored to the soil as such or

50 after being burnt. Returning straw directly to the field has been promoted as a source of organic

51 matter and a way to increase soil water holding capacity and its overall quality. As such, it is

52 thought to help maintain, or even to some extent restore, soil fertility (Lal et al., 2004). If the

53 residues are returned to the soil, farmers have to choose how to manage them using either

54 conventional tillage or alternatives such as reduced tillage. We define conventional tillage as a

55 tillage based on mouldboard ploughing which is commonly used in temperate regions and

56 reduced tillage as a tillage with reduced intensity and/or depth (Hiel et al., 2016; the practical

57 implementation of these techniques are specified in Table S1).

58 The precise impact of the restitution (or not) of residues and of the choice of tillage system to

59 apply to the soil-plant system remains unclear and seems to be highly dependent on the pedo-

60 climatic conditions (soil structure, moisture, macro fauna, etc.) (Powlson et al., 2011). For

61 instance, soil organic carbon (SOC) generally seems to slightly increase if residues are returned

62 to the soil, particularly in the long term (Chenu C. et al., 2014; Autret et al., 2016; Merante et al.,

63 2017). However, the actual quantification of straw incorporation effect on soil organic carbon

64 stocks shows conflicting results, as synthetized by (Poeplau et al., 2015), with studies reporting 
65 SOC losses, SOC stabilization or even non-significant or negligible impact. The effect of tillage 66 on SOC content is less clear. While some studies show an increase of SOC with reduced or no-

67 tillage (Arrouays et al., 2002; Smith, 2007; Garcia-Franco et al., 2015), others report no effect 68 (Dick, 1983; Dolan et al., 2006; Dikgwatlhe et al., 2014).

69 As Hiel et al. (2016) show in their review, the impact of crop residue management on crop 70 performance is also contradictory in the existing literature. The presence of residues seems to be 71 detrimental to crop germination as they can form a physical obstacle for seedlings (Arvidsson, 72 Etana \& Rydberg, 2014), can create a cold and humid micro-climate around the seed (Soane et 73 al., 2012) and provide a favourable habitat for slugs (Christian \& Miller, 1986) and plant 74 pathogens (Arvidsson, Etana \& Rydberg, 2014). In general, the literature show that weather conditions are the main factor influencing crop yields (Linden, Clapp \& Dowdy, 2000; Dam et al., 2005; Soon \& Lupwayi, 2012), and sometimes an interacting explanatory factor is the residue management (Riley, 2014). Residue retention tends to induce lower yields under wet weather conditions (effect on diseases and pests) (Riley, 2014) and higher yields in dry conditions (effect on water retention capacity) (Linden, Clapp \& Dowdy, 2000; Riley, 2014). There are also several studies reporting no effect on crop yields (Dam et al., 2005; Soon \& Lupwayi, 2012; Riley, 2014;

81 Brennan et al., 2014). Some specific results show that it is important to have the information on 82 the entire management type (i.e. residue in or out, type of tillage, tillage depth and timing,...) in 83 order to be able to assess the impact of the management on crop performance. Van den Putte et 84 al. (2010) showed for example that residue retention of winter cereals and maize, combined with 85 reduced tillage reduces yields in Europe. On the other hand, Blanco-Canqui \& Lal (2007) have 86 shown that residue removal can impede crop yield. 
87 The literature on the effect of residue management on nitrogen $(\mathrm{N})$ or phosphorus $(\mathrm{P})$ uptake by

88 plant is equally dispersed with no (for N: Brennan et al., 2014); positive (for N: Malhi et al., 89 2011; for P: Noack et al. 2014) or negative (for N: Soon \& Lupwayi, 2012; for P: Damon et al., 90 2014) effects reported by different authors. These differences are generally attributed to 91 differences in soil texture and/or initial nutrient status or residue quality (Kumar \& Goh, 1999; 92 Chen et al., 2014).

93 Interactions between crop residue management and the soil-water-plant system are complex and 94 inherently depend on the pedo-climatic conditions. Local assessment and system approach are 95 therefore necessary to come to relevant guidelines for residue management under specific pedo96 climatic conditions. The objective of our study was therefore to determine the effects of

97 contrasting crop residue management strategies on crop production and components of the soil

98 fertility, over a period of several years. Regarding crop production, we studied how residues 99 management strategy impacts on germination rate, biomass production and yield elaboration,

100 along with N, P and K exportation. The soil fertility components that were dynamically followed 101 were SOC, N, P and K contents and their repartition within the soil profile. The experiment was 102 conducted in the loam belt under temperate climatic conditions, taking into account common 103 crop rotations and local farming practices.

\section{2. Materials and methods}

\subsection{Site description}

106 The field experiment $\left(50^{\circ} 33^{\prime} 49.6^{\prime \prime} \mathrm{N}, 4^{\circ} 42^{\prime} 45.0^{\prime \prime} \mathrm{E}\right)$ was established on 1.7 ha of the experimental

107 farm of Gembloux Agro-Bio Tech, University of Liège, Belgium in 2008 and yield 108 measurements started in 2010. The soil is a Cutanic Luvisol (IUSS Working Group WRB, 2014). 109 According to the Walloon soil map (WalOnMap, 2018), the soil was silty with favourable natural 
110 drainage, containing $70-80 \%$ of silt, clay content of $18-22 \%$ of clay and $5-10 \%$ of sand. A

111 characterization of the spatial variability of certain chemical parameters was carried out in 2011

112 (maps available in Fig. S1). Descriptive statistics is presented in Table 1.

113 The climate is temperate ( $\mathrm{Cfb}$ in Köppen-Geiger classification (Peel, Finlayson \& McMahon,

114 2007)) with $819 \mathrm{~mm}$ average annual rain and $9.8^{\circ} \mathrm{C}$ annual average temperature. Weather data

115 were measured in a federal weather station located in Ernage (Belgium's Royal Meteorological

116 Institute), at $2.4 \mathrm{~km}$ from field site. An overview of monthly temperature and rainfall during the 117 experimental period is shown in Figs S2 and S3.

119 The field was designed as a Latin square disposal with four replications. Each plot was $15 \mathrm{~m}$ 120 wide and $40 \mathrm{~m}$ long. Crop residue management was defined as the combination of two practices:

121 (i) the fate of the crop residue and (ii) the type of tillage. Firstly the residue fate can be restitution 122 (IN) or exportation (OUT). It has to be noted that stubble and chaff are always left on the fields, 123 even if the rest of the residue is exported. Secondly, we considered two tillage types (see Table 124 2): conventional (CT, $25 \mathrm{~cm}$ depth) or reduced (RT, 7-10 cm depth). The different combinations 125 of these two aspects of residue management resulted in four treatments: CT-IN, CT-OUT, RT126 IN, RT-OUT.

127 The crop rotation during the experiment was: rapeseed (Brassica napus) in 2008-09, three 128 consecutive years of winter wheat (Triticum aestivum) in 2009-10, 2010-11 and 2011-12, 129 mustard (Sinapis alba) cover crop in 2012-13, faba bean (Vicia Faba) in 2013, winter wheat in 130 2014, oats (Avena sativa) and peas (Pisum sativum) mixed as cover crop in 2014-15, and finally

131 maize (Zea mays) in 2015. Sowing densities were 300 kernels $/ \mathrm{m}^{2}$ for winter wheat, 50 kernels $/ \mathrm{m}^{2}$ 132 for faba bean, and 13 kernels $/ \mathrm{m}^{2}$ for maize. Sowing process is detailed for each crop in Table S1. 
$133 \mathrm{~N}$ fertilisation (liquid $\mathrm{N}, \mathrm{UAN}$ at 39\%) followed the regional standards depending on the type of

134 crop. Rapeseed received two applications (at stem elongation stage: 31 and 32-50 on $\mathrm{BBCH}$

135 scale (Meier et al., 2009)) with a total of $160 \mathrm{~kg}$ of $\mathrm{N} / \mathrm{ha}$. Three applications were provided to

136 winter wheat (at tillering, stem elongation and flag leaf stage (26, 30 and 37-39 on BBCH scale))

137 with a total of $180 \mathrm{~kg}$ of N/ha. Faba bean was not fertilised and maize crop was fertilised with

$138120 \mathrm{~kg}$ of $\mathrm{N} / \mathrm{ha}$ before sowing. There was no external addition of $\mathrm{P}$ or $\mathrm{K}$. Crop protection

139 measures corresponded to the regional standards.

140 The detailed crop protocols (crop management, crop harvest, residue exportation, soil tillage,

141 fertilization and crop protection treatments) are available in Table S1.

143 We monitored the germination rate and growth dynamics during the season with an adapted

144 protocol for each crop type (Table 3). The determination of the germination rate consisted in

145 counting the number of seedlings on a definite area (Table 3). To quantify above-ground

146 biomass, plants were collected (according to crop protocol in Table 3) and their different parts

147 (shoot and ears, pods or cobs) were separated, counted and oven-dried at $60{ }^{\circ} \mathrm{C}$ for $72 \mathrm{~h}$. Grain

148 yield was assessed with an experimental harvester adapted to each crop by one passage per plot

149 (40 m long on a width dependent on the harvester, see specific crop protocol in Table 3). To

150 quantify the amount of remaining crop residues on the field, residues (i.e. OUT plots: stubble

151 and chaff, IN plots: all residue) were collected over a surface of $0.5 \mathrm{~m}$ wide and $2 \mathrm{~m}$ long

152 immediately after harvest, dried, weighed. These samples were also used to quantify the NPK

153 content of the remaining crop residues. Composite grain samples (maize and wheat grains; faba

154 been seeds) of $1 \mathrm{~kg}$ were prepared from the harvest hopper ( 1 sample per plot) for quantification

155 of NPK grain content. Both grains and residues were crushed before analysis. N content was 
156 measured using the Kjeldahl method (Bradstreet, 1965). Phosphate and potassium (K) levels in

157 plants were measured using a modified protocol of Zasoski \& Burau (1977). Samples were first

158 treated by a concentrated acid mix of $\mathrm{HNO}_{3}$ and $\mathrm{HClO}_{4}(1: 1)(15 \mathrm{ml}$ per $\mathrm{g}$ of sample). $\mathrm{K}$ content

159 was measured by a flame atomic absorption spectrometric method (Spectrometer Varian 220). P

160 was measured by colourimetry with molybdate and ammonium vanadate at $430 \mathrm{~nm}$ (Nanocolor

161 UV/VIS (Macherey-Nagel)). NPK content $[\mathrm{kg} / \mathrm{ha}]$ were calculated by multiplying the nutrient

162 content $[\%]$ by the biomass of the residue or grain $[\mathrm{kg} / \mathrm{ha}]$.

163

164

165

166

167

168

169

170

171

172

173

174

175

176

177

178

\subsection{Soil sampling and analyses}

Twice a year around April and October, we took ten soil subsamples (with a gouge auger of $2 \mathrm{~cm}$ diameter) to form a composite sample per plot at $0-10 \mathrm{~cm}, 10-20 \mathrm{~cm}$ and $20-30 \mathrm{~cm}$ depth. The fall sampling was usually either made after spring crop harvest and before winter wheat sowing or after winter wheat harvest and cover crop sowing. The spring sampling was made when climatic conditions were again favourable for winter wheat growth or after spring crop sowing. TOC was determined on a $1 \mathrm{~g}$ of dry soil (ground at $200 \mu \mathrm{m}$ ) by the Walkley-Black method (Blakemore, 1972): oxidation with $\mathrm{K}_{2} \mathrm{Cr}_{2} \mathrm{O}_{7}$ and $\mathrm{H}_{2} \mathrm{SO}_{4}$; titration of the excess of $\mathrm{K}_{2} \mathrm{Cr}_{2} \mathrm{O}_{7}$ with Mohr Salt $\left(\left(\mathrm{NH}_{4}\right)_{2} \mathrm{Fe}\left(\mathrm{SO}_{4}\right)_{2} \cdot 6 \mathrm{H}_{2} \mathrm{O}\right)$. Available soil nutrients were measured by stirring a $10 \mathrm{~g}$ sample of soil (air-dried and sieved at $2 \mathrm{~mm}$ ) for $30 \mathrm{~min}$ in $50 \mathrm{ml}$ of solution $\left(\mathrm{C}_{2} \mathrm{H}_{7} \mathrm{NO}_{2} 0.5 \mathrm{M}\right.$ and EDTA 0.02 M at pH 4.65 (Lakanen E. \& Erviö R., 1971)). After filtration, for the cations measurement, atomic emission was used for $\mathrm{K}$ while $\mathrm{P}$ was determined by colourimetry (colour reaction of (Murphy \& Riley, 1962), Nanocolor UV/VIS (Macherey-Nagel)).

In addition to the two overall soil sampling campaigns per growing season, soil nitrate content was measure more frequently to catch the dynamic of uptake during the growing phase of the main crops. Composite humid soil samples based on eight subsamples (sampled with gouge 
179 auger of $2 \mathrm{~cm}$ diameter) were used per plot at three depths: 0-30 cm, 30-60 $\mathrm{cm}$ and $60-90 \mathrm{~cm}$.

180 We used $\mathrm{KCl}$ extraction and a colourimetry method of reduction of nitrate to nitrite (using

181 Cadmium or Hydrazine) with a determination of nitrite ions by the modified Griess-Ilosvay

182 reaction (Bremner, 1965; Guiot, Goffart \& Destain, 1992).

183

184

185

186

187

188

189

190

192

194

195

196

197

198

\subsection{Statistical analyses}

Statistical analyses were performed with R software (R Core Team, 2015). The statistical analyses were systematically applied to assess the effect of crop residue management on crop and soil measurements, as follows. First, a 2-way ANOVA was performed, including the soil tillage and residue fate as fixed factors (with interaction) and the plot position (line and columns of the Latin square) as random factors. In case no interaction was highlighted between the fixed factors, we compared on the one hand, IN versus OUT treatments, and, on the other hand, RT versus $\mathrm{CT}$ treatments. These comparisons were then immediately made on the basis of the results of the 2-way ANOVA test. Contrarily, when an interaction between the fixed factors was significant, the four treatments (CT-IN, CT-OUT, RT-IN and RT-OUT) were intercompared and ranked using a post-hoc test (Student-Newman-Keuls - SNK). Analyses of variance (2-way ANOVA) and SNK tests were performed with the agricolae package (Mendiburu \& Simon, 2015). The conditions of application of the ANOVA test (normality of the distribution and homoscedasticity) were systematically checked on the residuals of the ANOVA, using respectively a Shapiro-Wilk test and a Bartlett test.

To study the evolution of soil parameters over the years, a linear mixed effects model was fitted using the lme4 package (Bates et al., 2014). To evaluate possible difference between treatments on the entire profile or per depth, the model was used with soil tillage and residue fate and their interaction as fixed factors, while dates and plots were random effects. To estimate whether 
202 stratification occurred in the soil parameters per crop residue management treatment, the mixed

203 effects model was used with the depths as a fixed factor and plots and dates as random effects. A

204 student's T-test was used to test for each treatment whether the soil factors of the last sampling

205 year and the first sampling year were significantly different.

206 3. Results

\subsection{Management of crop residues}

208 After seven crop rotations, the total amount of crop residue returned to the soil was on average

$20952 \%$ higher (i.e. $+28.8 \mathrm{t} / \mathrm{ha})$ for IN plots $(55.7 \mathrm{t} / \mathrm{ha})$ compared to OUT plots $(26.8 \mathrm{t} / \mathrm{ha})($ Table 4

210 and Table S2 for ANOVA summary). This was correlated with an increase in the amount of

211 nutrients in the residues (Tables S3 and S4) that were further restored to the soil.

212 While the stock (expressed in [kg/ha]; Table S3) of nutrients returned were greater in IN plots,

213 the OUT plots were characterised by greater content (expressed in $[\mathrm{g} / \mathrm{kg}]$; Table S5) of N (3

214 years out of 5) and P (2 years out of 5), due to a larger proportion of chaff in the remaining

215 residues. The trend was the opposite for K (2 years out of 5) (Tables S5 and S6).

216 The tillage treatment had no significant impact on the total amount of crop residues or on the

217 stock of nutrient (Table 4 and Tables S2 to S6).

218 Table 5 puts the emphasis on the different amounts of each nutrient (NPK) returned by the

219 different crops through their residues: e.g. while maize and faba bean brought higher $\mathrm{N}$ than

220 wheat, maize residues alone provided the highest quantity of $\mathrm{K}$ to the soil. 


\subsection{Soil results}

222

223

224

225

226

227

228

229

230

231

232

233

234 235

236

237

238

239

240

241

242 Phosphorus. Over the course of the experiment, P content in soil significantly decreased in the

\subsubsection{Total organic carbon}

The initial TOC content, over the entire arable depth $(0-30 \mathrm{~cm})$, was $11.7 \mathrm{~g} / \mathrm{kg}$. After 8 years, the different treatments (tillage or residue management) did not have a significant effect on the overall TOC content evolution (lmer : on tillage $\mathrm{F}=1.62, \mathrm{p}=0.22 ;$ on residue treatments $\mathrm{F}=$ $0.58, \mathrm{p}=0.46)$, although significant differences were observed during some specific years (Figure 1). The last measurement, in spring 2016, showed higher TOC under RT-IN compared to CT-OUT and RT-OUT.

We observed a clear stratification of the TOC content between the different soil depths $(0-10,10$ 20 and 20-30 cm depths) in the reduced tillage treatments (lmer $F=236.55, p<2.2 \mathrm{e}^{-16}$; Figure 1

B-D). More specifically, the TOC content increased over time in the $0-10 \mathrm{~cm}$ soil profile and, after 3.5 years, was systematically higher in RT than in CT (with the exception of autumn 2014). At that depth, higher TOC contents were observed in RT-IN than in RT-OUT. In the 10-20 cm soil layer, there were no differences between CT and RT. In the 20-30 cm soil layer, RT resulted in lower TOC content than CT from the third year of the trial onwards.

\subsubsection{Soil nutrients}

Nitrate. Averaged over the soil profile and over time, we did not observe differences in nitrate content between the different treatments, although some temporary differences were visible (Figure 2). The levels of nitrate within the 0 to $90 \mathrm{~cm}$ soil layer were highly variable over time and dominated by external inputs of fertilizer (black dots on Figure 2). Residue fate had no impact on the $\mathrm{NO}_{3}{ }^{-}$stock in any of the soil layers under any crop. $243 \quad 0-30 \mathrm{~cm}$ soil layer for all crop residue treatments, due to the absence of fertilisation during the 
244 course of the experiment (Fig. S4). In addition, there was a stratification of P under RT (RT-

245 OUT from autumn 2012 onwards ( $\left(\right.$ mer $\mathrm{F}=84.58, \mathrm{p}<2.2 \mathrm{e}^{-16}$ ) and RT-IN from spring 2014

246 onwards $\left.\left(\operatorname{lmer} F=34.06, p=3.6 \mathrm{e}^{-12}\right)\right)$. In the top layer $(0-10 \mathrm{~cm})$, these treatments showed a

247 higher decrease in P content than deeper in the profile. Our data do not suggest any significant

248 impact of crop residue on $P$ stocks in the soil ( $\operatorname{lmer} F=0.05, \mathrm{p}=0.83$ ).

249 Potassium. As for $\mathrm{P}, \mathrm{K}$ content in soil decreased from the beginning of the trial, as no $\mathrm{K}$

250 fertilisation was applied (Fig. S4). No particular effects of the different treatments were observed

251 on the total amount of $\mathrm{K}(\operatorname{lmer} \mathrm{F}=0.06, \mathrm{p}=0.81)$, except for the last 2 years of the experiment

252 (2015-2016), where IN plots showed a higher K content. Also for K a stratification was visible

253 ( $\left.\operatorname{lmer} \mathrm{F}=97.91, \mathrm{p}<2.2 \mathrm{e}^{-16}\right)$ with decreasing concentrations from top to bottom.

\subsection{Crop results}

255

256

257

258

259

260

261

262

263

264

\subsubsection{Germination rate}

The presence or absence of extra residues did not affect germination rate, except for winter wheat in 2013-14 where we observed a lower germination rate in the RT-IN treatment. Tillage type, however, did result in differences in germination rate. Table 6 (and ANOVA summary in Table S7) shows that three crops (out of six) had a higher germination rate in CT as compared to RT (winter wheat (2010-11), faba bean (2013) and winter wheat (2013-14)).

In Table 6, we see that residue fate and tillage type had an interacting effect on the global relative germination rate which is the average of all germination rates of all crops considered for a specific treatment, normalised to the sowing density. The germination rate in RT-IN was significantly lower than RT-OUT, itself lower than CT-IN and CT-OUT 


\section{3.3.2. Dynamic crop growth}

266 When looking at the dynamics of crop growth, except for two sampling dates on ears' growth

267 and two sampling dates on shoot's growth, no interactions were found between tillage and 268 residue management treatment. Observations and results of the ANOVA and SNK analysis are

269 reported in the supplementary material separately for ears and shoot growth (Tables S8 to S11).

270 The cumulated total produced biomass is presented in Fig. S5 (ANOVA summary in Table S12)

271 under graphical representation. It was therefore decided to analyse the impacts of tillage and

272 residue management individually.

273 Differences between residues management treatments (IN $v s$. OUT) were observed for crop

274 development. Incorporation of residues (IN plots) negatively impacted the dynamic of ears and

275 shoots during the first two crop seasons (winter wheat seasons 2009-10 and 2010-11). These

276 differences appeared in both cases after the ear emergence stage. These were more pronounced

277 for the shoot than the ear biomasses. In 2010, with weather conditions close to historical means,

278 lower biomass under IN treatments decreased over the crop growth period, but no negative

279 impact on yields were observed when residues were returned to the soil. In 2011, characterised

280 by a spring drought, the exportation of residue (OUT) was favourable to the shoot development

281 and to the early growth of ears. However, for this season, the final yield was not impacted by the

282 residue management treatment (IN vs. OUT), as detailed in the next section. Finally, one could

283 also notice that at the end of the 2014 crop season, while no differences were observed all along

284 the season, a statistical difference was reported on the last sampling date in favour of IN plots.

285 For all other sampling dates, no statistical differences were reported.

286 Reduced tillage mostly negatively impacted shoot crop development of winter wheat (2010-11),

287 faba bean (2013) and maize (2015) (Tables S8 and S9). This was probably due, in part, to the 
288 lower germination rate in RT plots for the winter wheat crop (2010-11) and faba bean (2013) (cfr

289 section 3.3.3). When computing the differences between tillage treatments (Figure 3 and Table

290 S12 for ANOVA summary), it was observed that the gap between treatments tended to decrease

291 for the different crops as they developed through the season. For faba bean no differences were

292 finally observed between the final biomass (Figure 3), the pods (Table S10 and S11) and the seed

293 yield (Table 7 - cfr section 3.3.3), while statistical differences between RT and CT remained for

294 maize shoot, cobs and grain yield cultivated in 2015 (Figure 3, Table S10 and S11, and Table 7 -

295 cfr section 3.3.4).

\subsubsection{Crop yield and quality}

297 Yearly grain yields were in general not influenced by residue fate or soil tillage (Table 7 and

298 Table S13 for ANOVA summary), except for a negative effect for reduced tillage for winter

299 wheat cultivated in 2010-11 (-9\%) and maize in $2015(-4 \%)$ and residue incorporation for winter

300 wheat in $2010-11(-10 \%$, year characterised by a spring drought, Figs. S2 and S3).

301 The cumulative grain yield since 2010 was significantly lower under reduced compared to

302 conventional tillage $(-3.4 \%$, Table 7$)$. No effect of residue fate was observed.

303 There was no significant effect of the treatments on NPK content of the harvested grain or seeds

304 (Table S14), except for marginally higher P content in winter wheat (in 2010-11) grains in IN

305 plots (P-value: 0.03 ) and a slightly lower K content under conventional tillage in 2 years out of 5

306 (Winter wheat in 2011-12, p-value: 0.01 ; Maize in 2015, p-value: 0.03 ).

308 No correlation was seen between germination rate and shoot dry weight except for faba bean

309 (2013) and a slight effect for winter wheat (2010-11) (Figure 4A). Grain yield was only 
310 positively correlated to germination rate for winter wheat (2010-11) (Figure 4B). Similarly, grain

311 yield was slightly correlated to shoot dry weight for that year only (Figure 4C).

312

\subsection{Integrated approach between crop production and soil chemistry}

313 A principal component analysis was performed to study the relationship between soil and plant

314 parameters (Figure 5). Plant and crop residue data are the sums (for residue biomass, shoot

315 biomass, yield and NPK stocks) or means (for germination rate and harvest index (HI)) of the all

316 crop data (the six crops grown between 2009 and 2015). We used soil data from the last spring

317 measurement in 2016.

318 The two principal components allowed to explain respectively $35 \%$ and $25 \%$ of the variance.

319 Treatments were easily differentiated by the two principal components (Figure 5-A). It appeared

320 that crop productivity (yield, shoot and total biomass) and quality ( $\mathrm{K}_{\text {grain }}, \mathrm{P}_{\text {grain }}$ and $\mathrm{N}_{\text {grain }}$ ) were

321 favoured by conventional tillage, as illustrated by the discrimination of treatments along the

322 second component (Y-Axis) of the PCA. Similarly, it seemed that the soil parameters (TOC, $\mathrm{K}_{\text {soil }}$

323 and to a lower extent $\mathrm{P}_{\text {soil }}$ ) were more positively influenced by the crop residue retention (Figure

324 5-B), as illustrated by the discrimination of treatments along the first component (X-Axis) of the 325 PCA.

\section{Discussion}

328 Overall, tillage influenced crop production more strongly than import or export of residues. The

329 strongest effect was seen in terms of germination rate and was even stronger for residue

330 incorporation treatments. RT resulted consistently in lower germination rates as also shown by

331 Brennan et al. (2014). Germination rate is strongly affected by seedbed soil moisture, soil 
332 structure and contact around the seed and soil temperature (Guérif et al., 2001). It is

333 acknowledged that crop residues can be a physical obstacle to crop emergence and a source of

334 phytotoxicity for crop seedlings (Morris et al., 2010). Moreover, the presence of crop residues

335 around seeds can impede adequate seed-to-soil contact needed for good crop emergence by

336 increasing the macroporosity which is known to decrease the degree of contact (Brown et al.,

337 1996). Nevertheless, the differences due to germination rate have the tendency to disappear at

338 later growth stages if no climatic extremes occur, since the plants generally compensate a lower

339 density with a better growth under favourable growth conditions as also observed by (Dam et al.,

340 2005).

341 Several studies report higher crop production levels under CT under temperate climate, when

342 compared to RT (Brennan et al., 2014; Pittelkow et al., 2014). However, the difference between

343 both systems remained small in the presented experiment, but confirmed, among else, by the

344 PCA analysis. Our results went in the direction of the conclusion of Van den Putte et al. (2010)

345 study of conservation agriculture in Europe showing a yield decline of $4.5 \%$ in RT systems as

346 compared to conventional systems. When confronting the crop results to the meteorological

347 conditions (Figure 3, Table 7 and Figs. S2 and S3) we believe that the CT production systems

348 might be less sensitive to inter-annual fluctuations of climatic conditions over different years

349 compared to the RT systems. Also, Brennan et al. (2014) highlighted that the residue fate was

350 less important than the tillage type for crop performance. Residue fate has a stronger effect on

351 crop production under drier climates and water limited conditions (Linden, Clapp \& Dowdy,

352 2000; Pittelkow et al., 2014).

353 The differences observed for germination rates or during crop growth seem to have little

354 influence on crop yield. A similar lack of correlation between shoot biomass and grain yield, as 
355 observed most strongly for faba bean and wheat (2014) in our study, has previously been

356 observed for legume crops (Araújo \& Teixeira, 2008). For winter wheat, it is likely that the

357 ability to produce more tillers at lower densities explains the recovery from lower germination

358 rates, as reported in the literature (Whaley et al., 2000; Gooding, Pinyosinwat \& Ellis, 2002).

359 Moreover, it is known that the flag leaf and ears are the main photosynthetic organs contributing

360 to grain filling (Sanchez-Bragado et al., 2014) which is an additional explanation why the entire

361 shoot biomass was not correlated to yield, especially during years with climate conditions close

362 to the historical means (i.e. winter 2009-10, 2011-12 and 2013-14). Winter wheat (2010-11) and

363 maize (2015) were the only crops with observable differences between treatments at the end of

364 crop development. We hypothesize that the spring drought during winter wheat development in

365 2010-11 impeded its ability to recover its potential yield as in the other years.

366 Except for the winter wheat 2010-11, our results did not show an increase in $\mathrm{N}$ grain stock. This

367 observation is in agreement with Brennan et al. (2014), but opposed to the results reported by

368 Malhi et al. (2011) or Soon \& Lupwayi (2012). The absence of crop residue treatment effects on

369 P grain content could be also due to the poor P content of crop residues. Regarding the small

370 differences observed in grain K content, Zörb, Senbayram \& Peiter (2014) mentioned that K

371 content in grain is not correlated to $\mathrm{K}$ supply and grain have relatively low $\mathrm{K}$ contents.

374 Over the seven years of this experiment, the effects of crop residue management on soil fertility 375 parameters showed few statistical differences in the early time of the trial. However, the results

376 were slowly magnifying, up to the point where differences became more systematically

377 significant, with clear stratification occurring over the different soil layer of the ploughing depth. 
378 Furthermore, our results (PCA analysis) confirmed a clear link between soil TOC, K content, and

379 to a lower extent $\mathrm{P}$ content, with residues management treatment (IN vs. OUT).

380 Even though the literature shows that residue incorporation could have a positive effect on the

381 stock of SOC (Chenu C. et al., 2014; Autret et al., 2016; Merante et al., 2017), we only observed

382 small effects on the TOC content. It should be noted that we cultivated wheat for 4 out of 7 years

383 and therefore our residues contain a large proportion of straw, which has already been shown to

384 be inefficient to increase TOC (Lemke et al., 2010; Poeplau et al., 2015). Just like previous

385 studies (Angers et al., 1997; Dolan et al., 2006; Gadermaier et al., 2012; Dimassi Bassem, 2013;

386 Riley, 2014; Dikgwatlhe et al., 2014), we have shown that reduced tillage provoked a

387 stratification of TOC. The absence of differences between TOC(CT-IN) and TOC(CT-OUT) can

388 be explained by a dilution effect (accumulation of organic matter in the top that is mixed through

389 ploughing) as well as by a potentially faster degradation rate, as reported by Lal et al. (2004).

390 The absence of any overall effect of residue treatment on the nitrate content was likely due to a

391 combination of factors. Firstly, the proportionally high amount of mineral N applied as fertiliser -

392 which respects the common practice in Belgium - reduced the effect of $\mathrm{N}$ returned by the

393 residues. Secondly, the straw incorporation effect might have had a short-term impact on soil

394 nitrate (Van Den Bossche A. et al.) rather than long term impact (Brennan et al., 2014). Such a

395 lack of impact was also reported by Stenberg et al. (1999).

396 The absence of residue treatment effects on P content in soil can be explained by the low P

397 content of crop residues. Damon et al. 2014 have shown that P availability is only increased for

398 large amounts of residues with high P content. A P content threshold of 2 to $3 \mathrm{mg} / \mathrm{g}$ of residue is

399 generally considered as the limit below which no impact should be expected. Under this value, 
400 immobilisation by microbial biomass occurs and P mineralization is hampered (Damon et al.

401 2014). In our study, $P$ content was $0.9 \mathrm{mg} / \mathrm{g}$ for wheat and maize residues and $1.6 \mathrm{mg} / \mathrm{g}$ for faba

402 bean crop, which means that we were consistently and considerably below this theoretical

403 threshold for P mineralization.

404 The decrease in $\mathrm{K}$ content was due to the lack of fertilisation during the trial (no dedicated $\mathrm{K}$

405 fertilisation or manure application was intentionally made between 2008 and 2016) but this

406 decrease is slight. Compared to $\mathrm{P}$ content, $\mathrm{K}$ content of residues was much higher. Furthermore,

407 as the mineralisation process is not involved, $\mathrm{K}$ is released in soil solution as soon as the plant

408 cells were dead (Schvartz, Decroux \& Muller, 2005). These combined effects probably explain

409 the slighter slope observed on the dynamics of $\mathrm{K}$. The stratification observed in $\mathrm{P}$ and $\mathrm{K}$ content

410 with reduced tillage was also reported by (Riley, 2014).

\section{5. Conclusion}

412 When looking within the available choices among the soil and crop management techniques,

413 crop production remains one of the most important drivers of farmer's decisions. However, the

414 impact of residue management and tillage treatment on crop production, and also on soil fertility,

415 are known to be highly dependent on the local pedo-climatic conditions, and the literature

416 usually focus on one of the aspects (soil or crop) and barely on multiple aspects at the same time.

417 This study aimed at analysing the impacts of crop residue management techniques on different

418 soil and crop parameters together, as interacting components of the agro-ecosystem, and as a

419 response to the local pedo-climatic conditions. We found out that, at the annual scale, crop

420 production was generally not significantly impacted by the different residue management

421 strategies. However, over the duration of the trial, while no effect of residue fate was reported 
422 (IN vs. OUT), the cumulative grain yield was found to be significantly lower $(-3.4 \%)$ under

423 reduced tillage (RT) compared to conventional tillage (CT).

424 In this seven-year experiment, small but gradually increasing differences between the different 425 crop residue management strategies were observed. After a few years, the TOC content in the 426 soil was higher only where the residues were incorporated and the tillage reduced. Overall, a 427 stratification of organic matter and nutrients was observed under reduced tillage, i.e. for TOC, P 428 and K. Crops grown on reduced tillage plots had a lower germination rate in some years, but in 429 two years out of three crops overcame this germination gap through compensation mechanisms 430 and finally yields were statistically equivalent.

431 Soil processes in general, and carbon dynamics in particular, are slow processes. Our study 432 reflects a system currently in transition, which will likely continue to evolve over the next 433 decade. Therefore, it will be of uttermost importance to continue the monitoring of this 434 experimental site in order to understand the long-term impact of residue management on crop 435 performance and soil quality and health.

436 Finally, when choosing among soil and crop management techniques, (among which the fate of 437 residues and the intensity of tillage that were analysed in this study are few examples), other 438 factors than the sole crop productivity should be included in the farmer's decision process, such 439 as fuel consumption, required working hours, greenhouse gas emissions (Lognoul et al., 2017;

440 analysis conducted on the same experiment), soil fauna (Degrune, 2017), long-term soil quality 441 and health. 
442

443

444 445 the statistical advices.

\section{Acknowledgements}

43 A special thanks to the entire technical team of the experimental farm for their helping hands in 444 the field. We also want to thank the CRA-W for their support. We also thank Yves Brostaux for

446

447

448

451

452

453

454

455

456

457

458

459

460

461

462

\section{Bibliography}

Angers DA., Bolinder MA., Carter MR., Gregorich EG., Drury CF., Liang BC., Voroney RP., Simard RR., Donald RG., Beyaert RP., Martel J. 1997. Impact of tillage practices on organic carbon and nitrogen storage in cool, humid soils of eastern Canada. Soil and Tillage Research 41:191-201. DOI: 10.1016/S0167-1987(96)01100-2.

Araújo AP., Teixeira MG. 2008. Relationships between grain yield and accumulation of biomass, nitrogen and phosphorus in common bean cultivars. Revista Brasileira de Ciência do Solo 32:1977-1986.

Arrouays D., Balesdent J., Germon JC., Jayet PA., Soussana JF., Stengel P. 2002. Increasing carbon stocks in French agricultural soil ? Sustainable Development.

Arvidsson J., Etana A., Rydberg T. 2014. Crop yield in Swedish experiments with shallow tillage and no-tillage 1983-2012. European Journal of Agronomy 52:307-315. DOI: 10.1016/j.eja.2013.08.002.

Autret B., Mary B., Chenu C., Balabane M., Girardin C., Bertrand M., Grandeau G., Beaudoin N. 2016. Alternative arable cropping systems: A key to increase soil organic carbon storage? Results from a 16 year field experiment. Agriculture, Ecosystems and Environment 232:150-164. DOI: 10.1016/j.agee.2016.07.008. 
463 Bates D., Mächler M., Bolker B., Walker S. 2014. Fitting Linear Mixed-Effects Models using 464 lme4. arXiv:1406.5823 [stat]. DOI: 10.18637/jss.v067.i01.

465 Blakemore 1972.Methods for chemical analysis of soils / L.C. Blakemore, P.L. Searle [and] B.K. 466 Daly. - Version details. Available at http://trove.nla.gov.au/version/42620262 (accessed $467 \quad$ February 20, 2017).

468 Blanco-Canqui H., Lal R. 2007. Soil and crop response to harvesting corn residues for biofuel 469 production. Geoderma 141:355-362. DOI: 10.1016/j.geoderma.2007.06.012.

BRADSTREET RB. (ed.) 1965. Copyright. In: The Kjeldahl Method for Organic Nitrogen. Academic Press, iv. DOI: 10.1016/B978-1-4832-3298-0.50002-3.

Bremner JM. 1965.Bremner, J.M. (1965) Inorganic Forms of Nitrogen. In: Black, C.A., et al., Eds., Methods of Soil Analysis, Part 2, Agronomy Monograph No. 9, ASA and SSSA, Madison, 1179-1237. - References - Scientific Research Publish. Available at http://www.scirp.org/(S(i43dyn45teexjx455qlt3d2q))/reference/ReferencesPapers.aspx?R eferenceID=1628091 (accessed September 25, 2017).

Brennan J., Hackett R., McCabe T., Grant J., Fortune RA., Forristal PD. 2014. The effect of tillage system and residue management on grain yield and nitrogen use efficiency in winter wheat in a cool Atlantic climate. European Journal of Agronomy 54:61-69. DOI: 10.1016/j.eja.2013.11.009.

Brown AD., Dexter AR., Chamen WCT., Spoor G. 1996. Effect of soil macroporosity and aggregate size on seed-soil contact. Soil and Tillage Research 38:203-216. DOI: 10.1016/S0167-1987(96)01030-6. 
484 Chen B., Liu E., Tian Q., Yan C., Zhang Y. 2014. Soil nitrogen dynamics and crop residues. A

485

486

487

488

489

490

491

492

493

494

495

496

497

498

499

500

501

502

503

504

505

review. Agronomy for Sustainable Development 34:429-442. DOI: 10.1007/s13593-0140207-8.

Chenu C., Klumpp K., Bispo A., Angers D., Colnenne C., Metay A. 2014. Stocker du carbone dans les sols agricoles : évaluation de leviers d'action pour la France. Innovations Agronomiques 37:23-37.

Christian DG., Miller DP. 1986. Straw incorporation by different tillage systems and the effect on growth and yield of winter oats. Soil and Tillage Research 8:239-252. DOI: 10.1016/0167-1987(86)90337-5.

Dam RF., Mehdi BB., Burgess MSE., Madramootoo CA., Mehuys GR., Callum IR. 2005. Soil bulk density and crop yield under eleven consecutive years of corn with different tillage and residue practices in a sandy loam soil in central Canada. Soil and Tillage Research 84:41-53. DOI: 10.1016/j.still.2004.08.006.

Damon PM., Bowden B., Rose T., Rengel Z. 2014. Crop residue contributions to phosphorus pools in agricultural soils: A review. Soil Biology and Biochemistry 74:127-137. DOI: 10.1016/j.soilbio.2014.03.003.

Degrune F. 2017. Assessing microbial diversity changes associated with different tillage and crop residue managements: study case in a loamy soil. Université de Liège, Liège, Belgique.

Dick WA. 1983. Organic Carbon, Nitrogen, and Phosphorus Concentrations and pH in Soil Profiles as Affected by Tillage Intensity1. Soil Science Society of America Journal 47:102. DOI: 10.2136/sssaj1983.03615995004700010021x. 
506 Dikgwatlhe SB., Kong FL., Chen ZD., Lal R., Zhang HL., Chen F. 2014. Tillage and residue 507 management effects on temporal changes in soil organic carbon and fractions of a silty 508 loam soil in the North China Plain. Soil Use and Management 30:496-506. DOI:

$509 \quad 10.1111 /$ sum.12143.

510 Dimassi Bassem J-PC. 2013. Changes in soil carbon and nitrogen following tillage conversion in 511 a long-term experiment in Northern France. Agriculture, Ecosystems \&amp; Environment 169:12-20. DOI: 10.1016/j.agee.2013.01.012.

513 Dolan MS., Clapp CE., Allmaras RR., Baker JM., Molina JAE. 2006. Soil organic carbon and 514 nitrogen in a Minnesota soil as related to tillage, residue and nitrogen management. Soil and Tillage Research 89:221-231. DOI: 10.1016/j.still.2005.07.015.

516 Gadermaier F., Berner A., Fließbach A., Friedel JK., Mäder P. 2012. Impact of reduced tillage 517 on soil organic carbon and nutrient budgets under organic farming. Renewable Agriculture and Food Systems 27:68-80. DOI: 10.1017/S1742170510000554.

519 Garcia-Franco N., Albaladejo J., Almagro M., Martínez-Mena M. 2015. Beneficial effects of reduced tillage and green manure on soil aggregation and stabilization of organic carbon in a Mediterranean agroecosystem. Soil and Tillage Research 153:66-75. DOI: 10.1016/j.still.2015.05.010.

Gooding MJ., Pinyosinwat A., Ellis RH. 2002. Responses of wheat grain yield and quality to seed rate. Journal of Agricultural Science 138:317-331. DOI:

526 Guiot J., Goffart J-P., Destain J-P. 1992. Le dosage des nitrates dans le sol. Bull. Rech. Agron. 527 Gembloux 27:61-74. 
528 Hiel M-P., Chélin M., Parvin N., Barbieux S., Degrune F., Lemtiri A., Colinet G., Degré A.,

529 Bodson B., Garré S. 2016. Crop residue management in arable cropping systems under a

530 temperate climate. Part 2: Soil physical properties and crop production. A review.

531 Biotechnologie, Agronomie, Société et Environnement 20:245-256.

532 IUSS Working Group WRB 2014. World reference base for soil resources 2014: international soil classification system for naming soils and creating legends for soil maps. Rome: FAO.

Kumar K., Goh KM. 1999. Crop Residues and Management Practices: Effects on Soil Quality, Soil Nitrogen Dynamics, Crop Yield, and Nitrogen Recovery.

Lakanen E., Erviö R. 1971. A comparison of eights extractants for the determination of plant available micronutrients in soils. :223-232.

Lal R., Griffin M., Apt J., Lave L., Morgan MG. 2004. Managing Soil Carbon. Science 304:393393. DOI: $10.1126 /$ science. 1093079.

541 Lemke RL., VandenBygaart AJ., Campbell CA., Lafond GP., Grant B. 2010. Crop residue removal and fertilizer $\mathrm{N}$ : Effects on soil organic carbon in a long-term crop rotation experiment on a Udic Boroll. Agriculture, Ecosystems \& Environment 135:42-51. DOI:

Linden DR., Clapp CE., Dowdy RH. 2000. Long-term corn grain and stover yields as a function of tillage and residue removal in east central Minnesota. Soil and Tillage Research 56:167-174. DOI: 10.1016/S0167-1987(00)00139-2. Vandenbol M., Aubinet M. 2017. Impact of tillage on greenhouse gas emissions by an 
agricultural crop and dynamics of N2O fluxes: Insights from automated closed chamber measurements. Soil \& Tillage Research 167. DOI: 10.1016/j.still.2016.11.008.

552 Malhi SS., Nyborg M., Solberg ED., Dyck MF., Puurveen D. 2011. Improving crop yield and N

553

554

555

556

557

558

559

560

561

562

563

564

565

566

567

568

569

570

571 uptake with long-term straw retention in two contrasting soil types. Field Crops Research 124:378-391. DOI: 10.1016/j.fcr.2011.07.009.

Meier U., Bleiholder H., Buhr L., Feller C., Hack H., Hess M., Lancashire PD., Schnock U., Stauls s R., Van Den Boom T., others 2009. The BBCH system to coding the phenological growth stages of plants-history and publications. Journal für Kulturpflanzen 61:41-52.

Mendiburu FD., Simon R. 2015. Agricolae - Ten years of an open source statistical tool for experiments in breeding, agriculture and biology. PeerJ PrePrints.

Merante P., Dibari C., Ferrise R., Sánchez B., Iglesias A., Lesschen JP., Kuikman P., Yeluripati J., Smith P., Bindi M. 2017. Adopting soil organic carbon management practices in soils of varying quality: Implications and perspectives in Europe. Soil and Tillage Research 165:95-106. DOI: 10.1016/j.still.2016.08.001.

Morris NL., Miller PCH., Orson JH., Froud-Williams RJ. 2010. The adoption of non-inversion tillage systems in the United Kingdom and the agronomic impact on soil, crops and the environment-A review. Soil and Tillage Research 108:1-15. DOI: 10.1016/j.still.2010.03.004.

Murphy J., Riley JP. 1962. A modified single solution method for the determination of phosphate in natural waters. Analytica Chimica Acta 27:31-36. DOI: 10.1016/S00032670(00)88444-5. 
572 Peel MC., Finlayson BL., McMahon TA. 2007. Updated world map of the Köppen-Geiger

573 climate classification. Hydrol. Earth Syst. Sci. 11:1633-1644. DOI: 10.5194/hess-11$574 \quad 1633-2007$.

575 Pittelkow CM., Liang X., Linquist BA., van Groenigen KJ., Lee J., Lundy ME., van Gestel N., 576 Six J., Venterea RT., van Kessel C. 2014. Productivity limits and potentials of the 577 principles of conservation agriculture. Nature advance online publication. DOI: $578 \quad 10.1038 /$ nature13809.

579 Poeplau C., Kätterer T., Bolinder MA., Börjesson G., Berti A., Lugato E. 2015. Low stabilization 580 of aboveground crop residue carbon in sandy soils of Swedish long-term experiments. $581 \quad$ Geoderma 237:246-255. DOI: 10.1016/j.geoderma.2014.09.010.

582 Powlson DS., Glendining MJ., Coleman K., Whitmore AP. 2011. Implications for Soil Properties 583 of Removing Cereal Straw: Results from Long-Term Studies. Agronomy Journal 103:279. DOI: $10.2134 /$ agronj2010.0146s.

R Core Team. 2015.R: a language and environment for statistical computing. Available at http://www.gbif.org/resource/81287 (accessed February 20, 2017).

Riley H. 2014. Grain yields and soil properties on loam soil after three decades with conservation tillage in southeast Norway. Acta Agriculturae Scandinavica Section B: Soil and Plant Science 64:185-202. DOI: 10.1080/09064710.2014.901406. 2014. Contribution of the ear and the flag leaf to grain filling in durum wheat inferred from the carbon isotope signature: Genotypic and growing conditions effects. Journal of Integrative Plant Biology 56:444-454. DOI: 10.1111/jipb.12106. 
594 Schvartz C., Decroux J., Muller J-C. 2005. Guide de la fertilisation raisonnée: grandes cultures 595 et prairies. France Agricole Editions.

596 Smith P. 2007. Land use change and soil organic carbon dynamics. Nutrient Cycling in 597 Agroecosystems 81:169-178. DOI: 10.1007/s10705-007-9138-y.

598 Soane BD., Ball BC., Arvidsson J., Basch G., Moreno F., Roger-Estrade J. 2012. No-till in 599 northern, western and south-western Europe: A review of problems and opportunities for 600 crop production and the environment. Soil and Tillage Research 118:66-87. DOI:

601 10.1016/j.still.2011.10.015.

602 Soon YK., Lupwayi NZ. 2012. Straw management in a cold semi-arid region: Impact on soil 603 quality and crop productivity. Field Crops Research 139:39-46. DOI:

604 10.1016/j.fcr.2012.10.010.

605 Stenberg M., Aronsson H., Lindén B., Rydberg T., Gustafson A. 1999. Soil mineral nitrogen and 606 607 nitrate leaching losses in soil tillage systems combined with a catch crop. Soil and Tillage Research 50:115-125. DOI: 10.1016/S0167-1987(98)00197-4.

608 Van Den Bossche A., De Bolle S., De Neve S., Hofman G.Effect of tillage intensity on N

609 mineralization of different crop residues in a temperate climate - ScienceDirect. Available at http://www.sciencedirect.com/science/article/pii/S0167198708002080 (accessed June

611 $15,2017)$.

612 Van den Putte A., Govers G., Diels J., Gillijns K., Demuzere M. 2010. Assessing the effect of 613 soil tillage on crop growth: A meta-regression analysis on European crop yields under 614 conservation agriculture. European Journal of Agronomy 33:231-241. DOI:

615 10.1016/j.eja.2010.05.008. 
616 WalonMap.WalOnMap. Available at http://geoportail.wallonie.be/walonmap (accessed April 24, 617 2018).

618 Whaley JM., Sparkes DL., Foulkes MJ., Spink JH., Semere T., Scott RK. 2000. The 619 physiological response of winter wheat to reductions in plant density. Annals of Applied $620 \quad$ Biology 137:165-177.

621 Zasoski RJ., Burau RG. 1977. A rapid nitric-perchloric acid digestion method for multi-element 622 tissue analysis. Communications in Soil Science and Plant Analysis 8:425-436. DOI:

623 $10.1080 / 00103627709366735$.

624 Zörb C., Senbayram M., Peiter E. 2014. Potassium in agriculture - Status and perspectives. 625 Journal of Plant Physiology 171:656-669. DOI: 10.1016/j.jplph.2013.08.008.

626

627 


\section{Figure 1}

Total organic carbon $[\mathrm{g} / \mathrm{kg}]$ present in the $(A) 0-30 \mathrm{~cm}$, (B) $0-10 \mathrm{~cm}$, (C) $10-20 \mathrm{~cm}$, (D) 20-30 cm soil layer.

Bottom ribbons represent the period covered by crops. Error bars depict the standard error between plots. Stars represent significant differences (ANOVA, p-value $<0.05$ ) between crop residue management strategies per sampling date. 

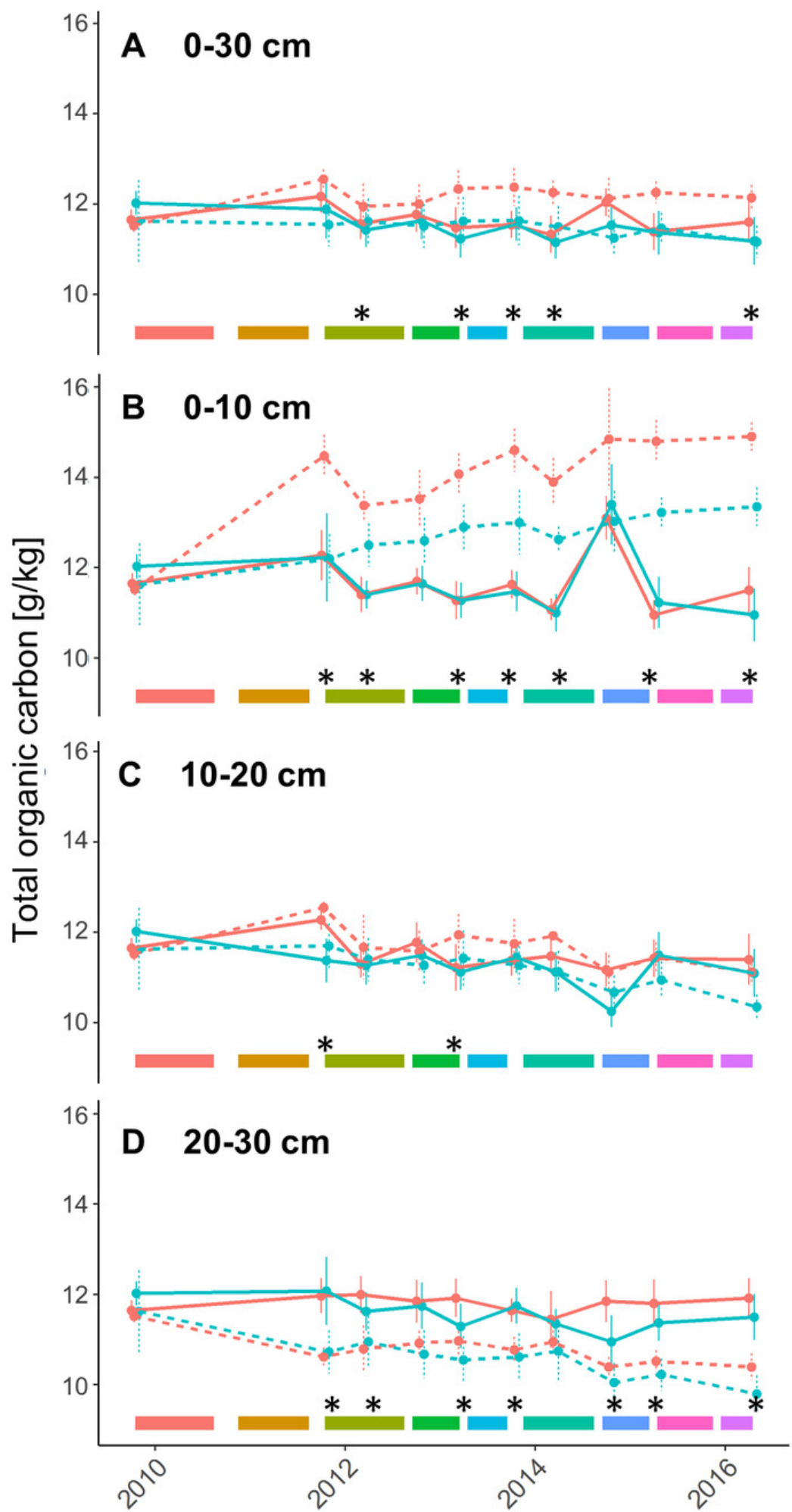

Residue Tillage Crop

treatment - CT 2009-10 Winter Wheat

$\rightarrow$ IN $\quad-$ RT 2010-11 Winter Wheat

$\rightarrow$ OUT 2011-12 Winter Wheat

2012-13 Cover crop

2013 Faba bean

2013-14 Winter Wheat

2014-15 Cover crop

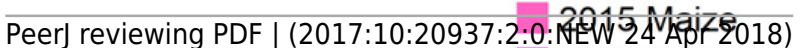


Figure 2

Nitrates $\left(\mathrm{N}-\mathrm{NO}_{3}{ }^{-}\right)[\mathrm{kg} / \mathrm{ha}$ ] present in the $(\mathrm{A})$ 0-30 cm, (B) $30-60 \mathrm{~cm},(\mathrm{C}) 60-90 \mathrm{~cm}$ depth layers of soil.

Bottom ribbons represent the period covered by crops. Error bars depict the standard error between plots. Vertical dot lines represent the date of crop fertilization. Black diamonds represent the quantity of nitrates added to the crop as mineral fertilization. Stars represent significant differences (ANOVA, p-value < 0.05) between crop residue management strategies per sampling date.

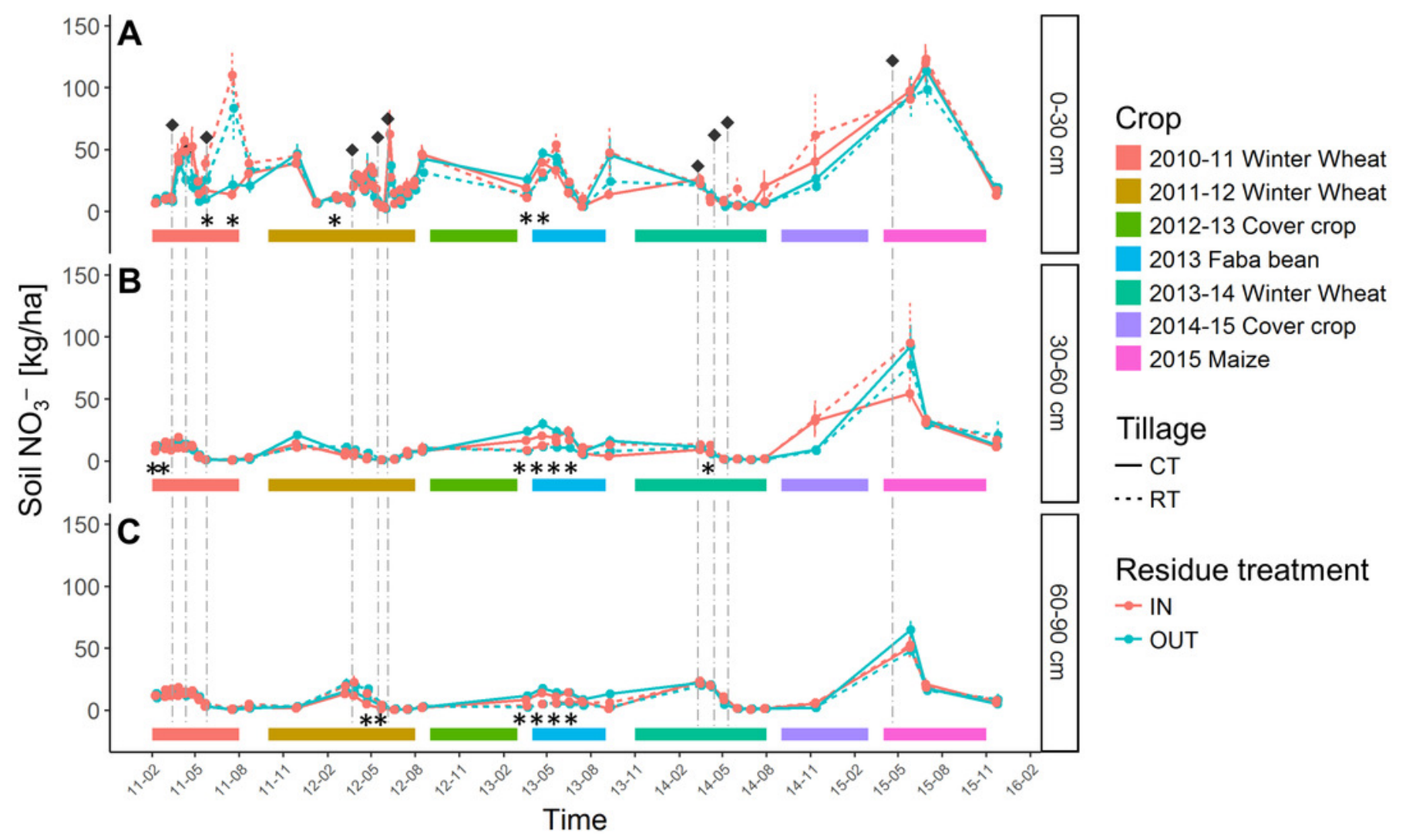




\section{Figure 3}

Relative crop biomass differences [\%] between conventional tillage (CT) and reduced tillage (RT), relative to $\mathrm{CT}$.

Error bars depict the standard error between plots. Stars represent significant differences (ANOVA, p-value $<0.05$ ) between crop residue management strategies per sampling date.

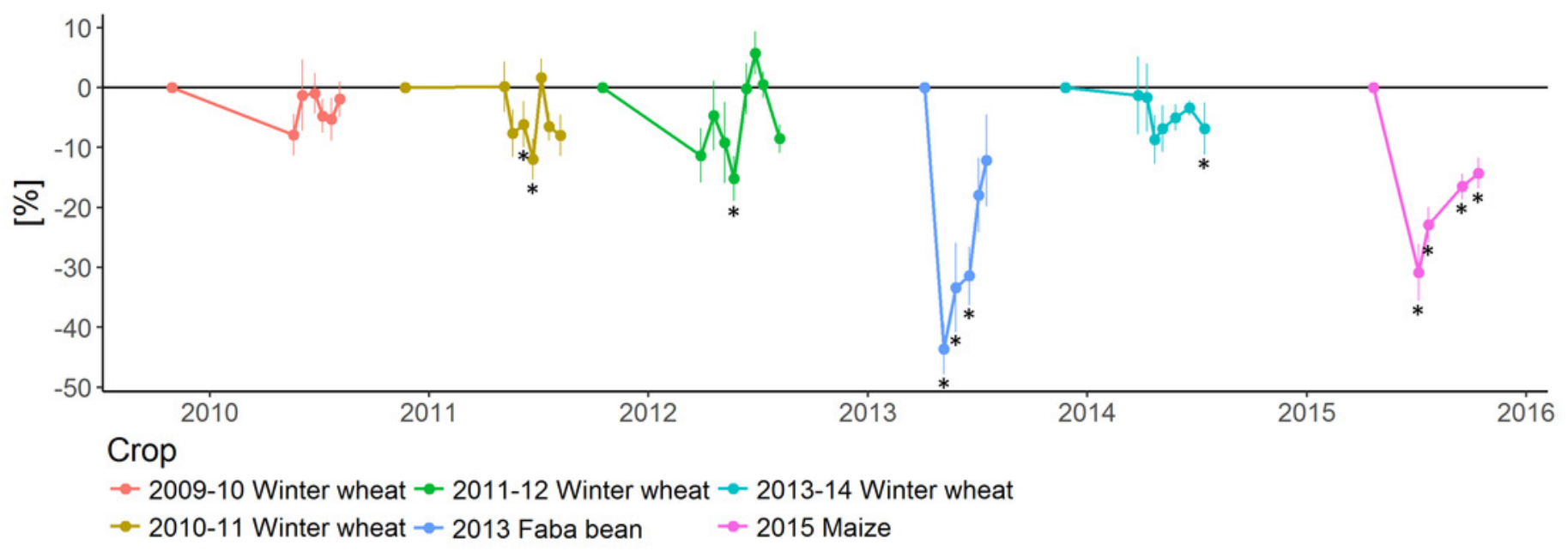




\section{Figure 4}

(A) Total shoot dry weight [t/ha] versus germination rate [\%]. (B) Grain yield versus [t/ha] germination rate [\%]. (C) Grain yield [t/ha] versus total shoot dry weight [t/ha].

Ellipses encompass $95 \%$ of the distribution. Below each graph, colour-related r-squared values and $p$-values are given for that crop.

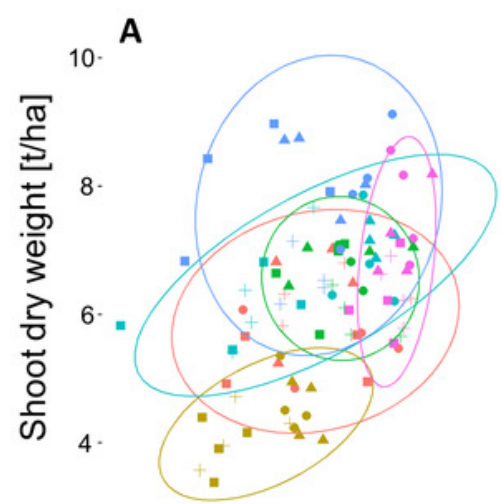

$40 \quad 60 \quad 80$

Germination rate [\%]

\begin{tabular}{ll|ll}
$\mathbf{R}^{\mathbf{2}}$ & $\mathbf{P}$ & $\mathbf{R}^{\mathbf{2}}$ & $\mathbf{P}$ \\
0.022 & 0.58 & 0.423 & 0.0006 \\
0.235 & 0.06 & 0.021 & 0.60 \\
0.002 & $\mathbf{0 . 8 7}$ & 0.144 & 0.15
\end{tabular}

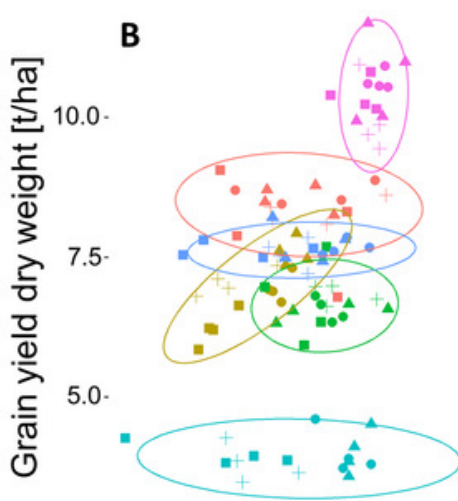

$40 \quad 60 \quad 80$ Germination rate [\%] \begin{tabular}{ll|ll}
$\mathbf{R}^{2}$ & $\mathbf{P}$ & $\mathbf{R}^{\mathbf{2}}$ & $\mathbf{P}$
\end{tabular} \begin{tabular}{ll|ll}
0.023 & 0.58 & 0.004 & 0.81
\end{tabular} \begin{tabular}{ll|ll}
0.59 & 0.0005 & 0 & 0.996
\end{tabular} \begin{tabular}{ll|ll}
0.003 & 0.83 & 0.007 & 0.77
\end{tabular}

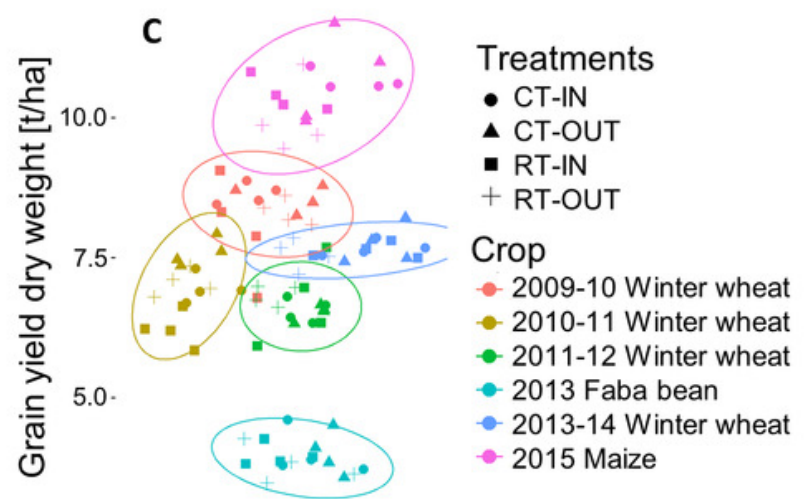

$\begin{array}{llll}4 & 6 & 8 & 10\end{array}$

Shoot dry weight [t/ha]

\begin{tabular}{ll|ll}
$\mathbf{R}^{2}$ & $\mathbf{P}$ & $\mathbf{R}^{\mathbf{2}}$ & $\mathbf{P}$
\end{tabular}

\begin{tabular}{ll|ll}
0.005 & 0.79 & 0.047 & 0.42
\end{tabular}

\begin{tabular}{ll|ll}
0.167 & 0.12 & 0.095 & 0.24
\end{tabular}

\begin{tabular}{ll|ll}
0.034 & 0.49 & 0.115 & 0.20
\end{tabular} 


\section{Figure 5}

(A) Unconstrained ordination analysis. (B) Correlations between soil and plant variables.

(A) Each dot represents an individual plot (from 1 to 16). Red is reduced tillage and blue is conventional tillage. Filled dots are for plots with incorporation of crop residues and empty dots are plots with exportation of crop residues. (B) Residue data are represented by purple arrows, Soil parameters are in red arrows and crop parameter in green. $\left(\mathrm{NO}_{3}{ }^{-}=\right.$nitrates in the $0-90 \mathrm{~cm}$ soil layer, $\mathrm{TOC}=$ total organic carbon, $\mathrm{K}=$ potassium, $\mathrm{P}=$ phosphorus, $\mathrm{N}=$ nitrogen. TOC, $K$ and $P$ in soil are value of the $0-30 \mathrm{~cm}$ final measurement. Plant and crop residue data are the accumulation (Residue biomass, shoot biomass, yield, NPK stock) or mean (germination rate, harvest index $(\mathrm{HI})$ ) of the all crop data. Soil data are the data measured in spring 2016 (last measurement).
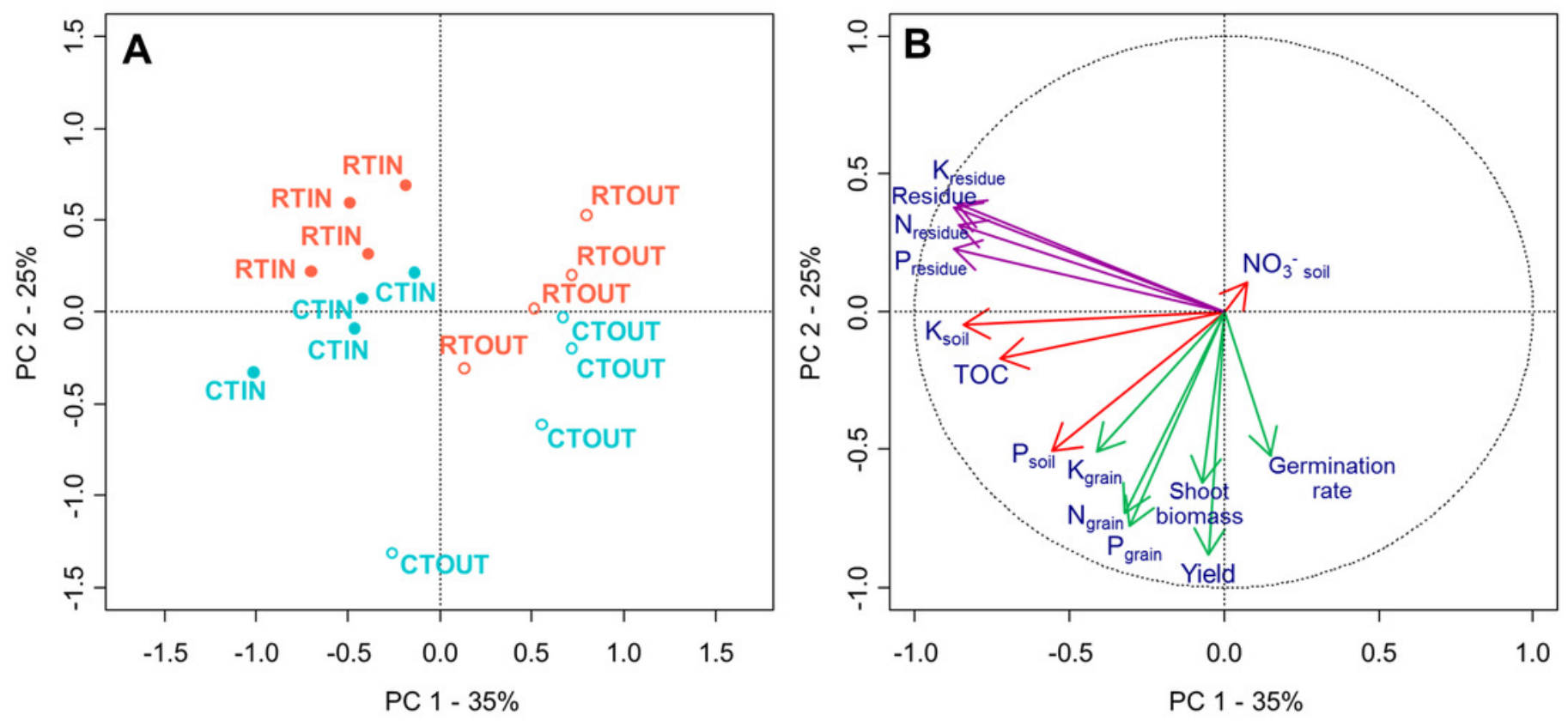


\section{Table $\mathbf{1}$ (on next page)}

Descriptive statistics of soil fertility indicators within the experimental fields on the 0-30 $\mathrm{cm}$ soil layer. 
1

\begin{tabular}{llllll}
\hline $\mathbf{N}^{1}=\mathbf{1 0 7}$ & $\mathbf{p H ~ K C l}$ & $\mathbf{T O C}[\mathbf{g} / \mathbf{k g}]$ & $\mathbf{P}[\mathbf{g} / \mathbf{k g}]$ & $\mathbf{K}[\mathbf{g} / \mathbf{k g}]$ & $\mathbf{C a}[\mathbf{g} / \mathbf{k g}]$ \\
\hline $\mathbf{M e a n}^{\prime} \mathbf{s d}^{\mathbf{2}}$ & $6.79 \pm 0.19$ & $12.7 \pm 1.2$ & $0.149 \pm 0.049$ & $0.162 \pm 0.027$ & $2.56 \pm 0.37$ \\
$\mathbf{C V}^{\mathbf{3}}$ & 2.8 & 9.4 & 0.329 & 0.167 & 0.144 \\
$\mathbf{M i n} / \mathbf{M a x}$ & $6.4 / 7.3$ & $9.4 / 16$ & $0.65 / 0.248$ & $0.105 / 0.222$ & $2.05 / 3.69$ \\
\hline
\end{tabular}

2 ${ }^{1}$ number of sample, ${ }^{2}$ standard deviation, ${ }^{3}$ coefficient of variation

3 
Table 2 (on next page)

Comparison of conventional and reduced tillage treatments. 


\begin{tabular}{|c|c|}
\hline Period & CONVENTIONAL TILLAGE \\
\hline After harvest & $\begin{array}{c}\text { Stubble breaking } \\
\text { Tool : tine stubble cultivator } \\
\text { Depth }: 7-10 \mathrm{~cm}\end{array}$ \\
\hline $\begin{array}{l}\text { Few days } \\
\text { before sowing }\end{array}$ & $\begin{array}{l}\text { Ploughing } \\
\text { Tool : moldboard plough } \\
\text { Depth : } 25 \mathrm{~cm}\end{array}$ \\
\hline Sowing day & $\begin{array}{l}\text { Seedbed preparation } \\
\text { Tool: dual cultivator with tines and rolls in front of the tractor and rotary harrow } \\
\text { followed by wedge ring roller. } \\
\text { The sowing machine is either mounted behind the wedge ring roller (cereals and faba } \\
\text { bean) or either an extra passage with a precision spaced planter (maize) is done. } \\
\text { Depth : } 7-10 \mathrm{~cm}\end{array}$ \\
\hline
\end{tabular}

1 
Table 3 (on next page)

Details of crop specific measurement protocols. 


\begin{tabular}{clll}
\hline & Winter wheat & Faba bean & Maize \\
\hline $\begin{array}{c}\text { Germination } \\
\text { rate }\end{array}$ & $\begin{array}{l}\text { Four repetitions of a } \\
\text { square of } 0.25 \mathrm{~m}^{2}\end{array}$ & $\begin{array}{l}\text { Four repetitions of a } \\
\text { square of } 0.25 \mathrm{~m}^{2}\end{array}$ & $\begin{array}{l}\text { Two plant rows of } 10 \mathrm{~m} \\
\text { long }\end{array}$ \\
$\begin{array}{c}\text { Above- } \\
\text { ground } \\
\text { biomass }\end{array}$ & $\begin{array}{l}\text { Two repetitions of } 3 \\
\text { plant rows of } 50 \mathrm{~cm} \text { long }\end{array}$ & $\begin{array}{l}\text { Two repetitions of a } \\
\text { square of } 0.25 \mathrm{~m}^{2}\end{array}$ & $\begin{array}{l}\text { Two plant rows of } 3 \mathrm{~m} \\
\text { long }\end{array}$ \\
Harvest & $\begin{array}{l}\text { With experimental } \\
\text { combine of } 2 \mathrm{~m} \text { wide }\end{array}$ & $\begin{array}{l}\text { With experimental } \\
\text { combine of } 2 \mathrm{~m} \text { wide }\end{array}$ & $\begin{array}{l}\text { With experimental } \\
\text { combine of } 1.5 \mathrm{~m} \text { wide } \\
\text { i.e. } 2 \text { sowing lines }\end{array}$ \\
\hline
\end{tabular}




\section{Table 4 (on next page)}

Descriptive statistics of crop residues dry weight remaining on the field [\%, \pm standard error] for the crops grown during the study period 2009-2015.

For each crop, treatments means with different letters are significantly different (ANOVA, pvalue $<0.05$ ). (WW: winter wheat, $C T$ : conventional tillage, $R T$ : reduced tillage, $I N$ : incorporation of crop residue, OUT: exportation of crop residues). 


\begin{tabular}{|c|c|c|c|c|c|c|c|c|}
\hline & \multicolumn{4}{|c|}{ Interaction between fixed factors } & \multicolumn{4}{|c|}{ No interaction between factors } \\
\hline & \multicolumn{4}{|c|}{ Crop residue management } & \multicolumn{2}{|l|}{ Residue fate } & \multicolumn{2}{|c|}{ Tillage type } \\
\hline & CT-IN & CT-OUT & RT-IN & RT-OUT & IN & OUT & $\mathrm{CT}$ & RT \\
\hline Rapeseed 2008-09 & $8.17 \pm 0.35$ & $1.54 \pm 0.08$ & $8.78 \pm 0.38$ & $1.68 \pm 0.08$ & $8.48^{a} \pm 0.26$ & $1.61^{b} \pm 0.06$ & $4.86^{\mathrm{a}} \pm 1.26$ & $5.23^{\mathrm{a}} \pm 1.35$ \\
\hline WW 2009-10 & $4.80 \pm 0.15$ & $2.89 \pm 0.17$ & $5.31 \pm 0.19$ & $3.91 \pm 0.32$ & $5.05^{a} \pm 0.15$ & $3.40^{b} \pm 0.25$ & $3.84^{b} \pm 0.38$ & $4.61^{\mathrm{a}} \pm 0.32$ \\
\hline WW 2010-11 & $5.73 \pm 1.12$ & $2.76 \pm 0.29$ & $4.48 \pm 0.48$ & $2.38 \pm 0.29$ & $5.10^{\mathrm{a}} \pm 0.61$ & $2.57^{b} \pm 0.20$ & $4.25^{\mathrm{a}} \pm 0.78$ & $3.43^{\mathrm{a}} \pm 0.47$ \\
\hline WW 2011-12 & $8.36 \pm 1.08$ & $4.55 \pm 0.52$ & $8.31 \pm 0.70$ & $4.40 \pm 0.35$ & $8.33^{a} \pm 0.60$ & $4.48^{b} \pm 0.29$ & $6.45^{\mathrm{a}} \pm 0.91$ & $6.35^{\mathrm{a}} \pm 0.82$ \\
\hline Cover crop 2012-13 & $1.73 \pm 0.09$ & $1.88 \pm 0.17$ & $0.85 \pm 0.09$ & $0.96 \pm 0.10$ & $1.29^{\mathrm{a}} \pm 0.18$ & $1.42^{\mathrm{a}} \pm 0.19$ & $1.80^{\mathrm{a}} \pm 0.09$ & $0.91^{b} \pm 0.06$ \\
\hline Faba 2013 & $6.79 \pm 0.38$ & $3.38 \pm 0.12$ & $6.06 \pm 0.29$ & $2.86 \pm 0.40$ & $6.43^{a} \pm 0.26$ & $3.12^{b} \pm 0.22$ & $5.09^{a} \pm 0.67$ & $4.46^{\mathrm{a}} \pm 0.65$ \\
\hline WW 2013-14 & $9.34 \pm 1.45$ & $4.94 \pm 0.31$ & $9.61 \pm 0.20$ & $4.48 \pm 0.33$ & $9.48^{a} \pm 0.68$ & $4.71^{b} \pm 0.23$ & $7.14^{\mathrm{a}} \pm 1.08$ & $7.04^{\mathrm{a}} \pm 0.99$ \\
\hline Cover crop 2014-15 & $1.88 \pm 0.13$ & $1.92 \pm 0.13$ & $2.58 \pm 0.12$ & $2.47 \pm 0.14$ & $2.23^{\mathrm{a}} \pm 0.16$ & $2.20^{\mathrm{a}} \pm 0.14$ & $1.90^{b} \pm 0.09$ & $2.52^{a} \pm 0.09$ \\
\hline Maize 2015 & $10.07 \pm 0.90$ & $3.31 \pm 0.32$ & $8.46 \pm 0.40$ & $3.38 \pm 0.48$ & $9.27^{\mathrm{a}} \pm \mathbf{0 . 5 5}$ & $3.34^{b} \pm 0.27$ & $6.69^{\mathrm{a}} \pm 1.35$ & $5.92^{\mathrm{a}} \pm 1.00$ \\
\hline Global rate & $56.86 \pm 1.98$ & $27.16 \pm 0.82$ & $54.44 \pm 0.57$ & $26.51 \pm 1.00$ & $55.65^{a} \pm 1.06$ & $26.84^{b} \pm 0.611$ & $42.01^{\mathrm{a}} \pm 5.7$ & $40.48^{\mathrm{a}} \pm 5.3$ \\
\hline
\end{tabular}




\section{Table 5 (on next page)}

Effect of residue treatment on the NPK stock of crop residues [kg/ha, \pm standard deviation] restituted to the soil per type of crop residue source.

Wheat values came from the mean of three years of experiments in winter wheat. For each type of nutrient and crop, treatments with different letters are significantly different (ANOVA, p-value < 0.05). (IN: incorporation of crop residue, OUT: exportation of crop residues). 


\begin{tabular}{llll}
\hline Nutrient & Crop & \multicolumn{2}{l}{ Residue Treatment } \\
& & IN & OUT \\
\hline $\mathrm{N}[\mathrm{kg} / \mathrm{ha}]$ & Wheat & $\mathbf{3 9 . 6}^{\mathbf{a}} \pm \mathbf{1 4 . 3}$ & $\mathbf{2 0 . 6}^{\mathbf{b}} \pm \mathbf{6 . 7}$ \\
& Faba bean & $\mathbf{6 3 . 9}^{\mathbf{a}} \pm \mathbf{1 4 . 7}$ & $\mathbf{4 3 . 5}^{\mathbf{b}} \pm \mathbf{1 0 . 2}$ \\
& Maize & $\mathbf{6 0 . 2}^{\mathrm{a}} \pm \mathbf{1 3 . 8}$ & $\mathbf{2 2 . 3}^{\mathbf{b}} \pm \mathbf{5 . 4}$ \\
$\mathrm{P}[\mathrm{kg} / \mathrm{ha}]$ & Wheat & $\mathbf{5 . 7}^{\mathbf{a}} \pm \mathbf{2 . 5}$ & $\mathbf{3 . 0}^{\mathbf{b}} \pm \mathbf{1 . 3}$ \\
& Faba bean & $\mathbf{8 . 6}^{\mathbf{a}} \pm \mathbf{3 . 4}$ & $\mathbf{4 . 4}^{\mathbf{b}} \pm \mathbf{1 . 5}$ \\
& Maize & $\mathbf{7 . 9}^{\mathbf{a}} \pm \mathbf{0 . 8}$ & $\mathbf{3 . 0}^{\mathbf{b}} \pm \mathbf{0 . 8}$ \\
$\mathrm{K}[\mathrm{kg} / \mathrm{ha}]$ & Wheat & $\mathbf{2 9 . 5}^{\mathbf{a}} \pm \mathbf{2 1 . 5}$ & $\mathbf{1 0 . 3}^{\mathbf{b}} \pm \mathbf{5 . 6}$ \\
& Faba bean & $\mathbf{4 2 . 2}^{\mathbf{a}} \pm \mathbf{1 2 . 1}$ & $\mathbf{1 3 . 8}^{\mathbf{b}} \pm \mathbf{3 . 5}$ \\
& Maize & $\mathbf{9 5 . 6}^{\mathbf{a}} \pm \mathbf{2 7 . 9}$ & $\mathbf{2 6 . 9} \pm \mathbf{4 . 3}$ \\
\hline
\end{tabular}

1 


\section{Table 6 (on next page)}

Descriptive statistics for germination rate $[\%, \pm$ standard error] for the crops grown during the study period 2009-2015.

For each crop, treatments means with different letters are significantly different (ANOVA, pvalue $<0.05$ ). (WW: winter wheat, CT: conventional tillage, RT: reduced tillage, IN: incorporation of crop residue, OUT: exportation of crop residues, Global rate is the average of all germination rates of all crops considered for a specific treatment, normalized to the sowing density). 


\begin{tabular}{|c|c|c|c|c|c|c|c|c|}
\hline & \multicolumn{4}{|c|}{ Interaction between fixed factors } & \multicolumn{4}{|c|}{ No interaction between factors } \\
\hline & \multicolumn{4}{|c|}{ Crop residue management } & \multicolumn{2}{|c|}{ Residue fate } & \multicolumn{2}{|l|}{ Tillage type } \\
\hline & CT-IN & CT-OUT & RT-IN & RT-OUT & IN & OUT & $\mathrm{CT}$ & RT \\
\hline WW 2009-10 & $65.8 \pm 5.6$ & $63.4 \pm 3.1$ & $61.7 \pm 5.9$ & $66.8 \pm 4.9$ & $63.7^{\mathrm{a}} \pm 3.8$ & $65.1^{\mathrm{a}} \pm 2.8$ & $64.6^{\mathrm{a}} \pm 3.0$ & $64.2^{\mathrm{a}} \pm 3.7$ \\
\hline WW 2010-11 & $60.5 \pm 0.9$ & $62.9 \pm 1.1$ & $49.1 \pm 1.5$ & $51.7 \pm 3.1$ & $54.8^{\mathrm{a}} \pm 2.3$ & $57.3^{\mathrm{a}} \pm 2.6$ & $61.7^{\mathrm{a}} \pm 0.8$ & $50.4^{b} \pm 1.7$ \\
\hline WW 2011-12 & $69.3 \pm 1.1$ & $69.0 \pm 4.6$ & $65.0 \pm 2.5$ & $71.0 \pm 2.4$ & $67.1^{\mathrm{a}} \pm 1.5$ & $70.0^{\mathrm{a}} \pm 2.4$ & $69.1^{\mathrm{a}} \pm 2.2$ & $68.0^{\mathrm{a}} \pm 2.0$ \\
\hline Faba 2013 & $72.3 \pm 2.1$ & $74.3 \pm 0.9$ & $50.5 \pm 6.3$ & $55.5 \pm 2.9$ & $61.4^{\mathrm{a}} \pm 5.1$ & $64.9^{\mathrm{a}} \pm 3.8$ & $73.3^{a} \pm 1.1$ & $53.0^{b} \pm 3.3$ \\
\hline WW 2013-14 & $72.0^{a} \pm 1.8$ & $65.4^{\mathrm{a}} \pm 3.0$ & $53.7^{\mathrm{b}} \pm 5.3$ & $62.7^{\mathrm{ab}} \pm 1.8$ & $62.8 \pm 4.3$ & $64.0 \pm 1.7$ & $68.7 \pm 2.0$ & $58.2 \pm 3.1$ \\
\hline Maize 2015 & $78.6 \pm 0.8$ & $78.2 \pm 1.9$ & $75.1 \pm 1.8$ & $77.1 \pm 0.9$ & $76.9^{\mathrm{a}} \pm 1.1$ & $77.6^{\mathrm{a}} \pm 1.0$ & $78.4^{\mathrm{a}} \pm 0.9$ & $76.1^{\mathrm{a}} \pm 1.0$ \\
\hline Global rate & $69.7^{\mathrm{a}} \pm 1.3$ & $68.9^{a} \pm 1.1$ & $59.2^{\mathrm{c}} \pm 2.6$ & $64.1^{b} \pm 1.6$ & $64.4 \pm 2.4$ & $66.5 \pm 1.3$ & $69.3 \pm 0.8$ & $61.6 \pm 1.7$ \\
\hline
\end{tabular}




\section{Table 7 (on next page)}

Descriptive statistics of yield dry weight $[\%, \pm$ standard error] for the crops grown during the study period 2009-2015.

For each crop, treatments means with different letters are significantly different (ANOVA, pvalue $<0.05$ ). (WW: winter wheat, CT: conventional tillage, RT: reduced tillage, IN: incorporation of crop residue, OUT: exportation of crop residues). 


\begin{tabular}{|c|c|c|c|c|c|c|c|c|}
\hline & \multicolumn{4}{|c|}{ Interaction between fixed factors } & \multicolumn{4}{|c|}{ No interaction between factors } \\
\hline & \multicolumn{4}{|c|}{ Crop residue management } & \multicolumn{2}{|c|}{ Residue fate } & \multicolumn{2}{|l|}{ Tillage type } \\
\hline & CT-IN & CT-OUT & RT-IN & RT-OUT & IN & OUT & $\mathrm{CT}$ & RT \\
\hline WW 2009-10 & $8.64 \pm 0.09$ & $8.56 \pm 0.12$ & $8.01 \pm 0.47$ & $8.32 \pm 0.12$ & $8.33^{\mathrm{a}} \pm 0.25$ & $8.44^{\mathrm{a}} \pm 0.09$ & $8.60^{\mathrm{a}} \pm 0.07$ & $8.17^{\mathrm{a}} \pm 0.23$ \\
\hline WW 2010-11 & $6.95 \pm 0.13$ & $7.59 \pm 0.12$ & $6.23 \pm 0.16$ & $7.05 \pm 0.12$ & $6.59^{\mathrm{a}} \pm 0.17$ & $7.32^{b} \pm 0.13$ & $7.27^{\mathrm{a}} \pm 0.15$ & $6.64^{b} \pm 0.18$ \\
\hline WW 2011-12 & $6.56 \pm 0.11$ & $6.53 \pm 0.07$ & $6.73 \pm 0.38$ & $6.83 \pm 0.09$ & $6.65^{\mathrm{a}} \pm 0.19$ & $6.68^{\mathrm{a}} \pm 0.08$ & $6.54^{\mathrm{a}} \pm 0.06$ & $6.78^{\mathrm{a}} \pm 0.18$ \\
\hline Faba 2013 & $4.01 \pm 0.20$ & $4.02 \pm 0.20$ & $3.98 \pm 0.10$ & $3.81 \pm 0.17$ & $3.99^{\mathrm{a}} \pm 0.10$ & $3.91^{\mathrm{a}} \pm 0.13$ & $4.01^{\mathrm{a}} \pm 0.13$ & $3.90^{\mathrm{a}} \pm 0.10$ \\
\hline WW 2013-14 & $7.67 \pm 0.07$ & $7.74 \pm 0.18$ & $7.63 \pm 0.07$ & $7.56 \pm 0.14$ & $7.65^{\mathrm{a}} \pm 0.05$ & $7.65^{\mathrm{a}} \pm 0.11$ & $7.71^{\mathrm{a}} \pm 0.09$ & $7.60^{\mathrm{a}} \pm 0.07$ \\
\hline Maize 2015 & $10.66 \pm 0.09$ & $10.66 \pm 0.42$ & $10.40 \pm 0.15$ & $9.99 \pm 0.33$ & $10.53^{\mathrm{a}} \pm 0.09$ & $10.32^{\mathrm{a}} \pm 0.28$ & $10.66^{\mathrm{a}} \pm 0.20$ & $10.19^{b} \pm 0.19$ \\
\hline Global rate & $44.49 \pm 0.03$ & $45.10 \pm 0.62$ & $42.98 \pm 0.45$ & $43.57 \pm 0.45$ & $43.73^{\mathrm{a}} \pm 0.35$ & $44.34^{\mathrm{a}} \pm 0.46$ & $44.79^{\mathrm{a}} \pm 0.31$ & $43.27^{b} \pm 0.32$ \\
\hline
\end{tabular}

